\begin{tabular}{|c|c|c|c|}
\hline \multirow{2}{*}{$\begin{array}{l}\text { LARUS } \\
\text { Hrvatska akademija } \\
\text { znanosti i umjetnosti }\end{array}$} & $\begin{array}{c}54 \\
(2019)\end{array}$ & $\begin{array}{l}\text { 7-22 str. } \\
1 \text { tablica, } 5 \text { slika }\end{array}$ & Zagreb 2019 \\
\hline & \multicolumn{3}{|c|}{$\begin{array}{c}\text { Primljeno 20.9.2019. } \\
\text { Prihvaćeno na sjednici Razreda za prirodne znanosti HAZU 21.11.2019. }\end{array}$} \\
\hline
\end{tabular}

\title{
STATUS OF THE RED KITE Milvus milvus IN CROATIA, BASED ON TELEMETRY RESEARCH: SPATIOTEMPORAL DISTRIBUTION AND NEW BREEDING RECORD
}

Status crvene lunje Milvus milvus u Hrvatskoj na temelju satelitskog praćenja: prostorno i vremensko pojavljivanje te ponovno gniježđenje

ADRIAN TOMIK ${ }^{1}$, JOSIP LEDINŠĆAK ${ }^{2}$, DORA DVORŽAK ${ }^{2}$, JELENA KRALJ ${ }^{3}$, IVAN LITERÁK ${ }^{4}$, HYNEK MATUŠÍ́K ${ }^{5}$, STANISLAV VYHNAL ${ }^{4}$, DAVID HORAL ${ }^{6}$, RAINER RAAB ${ }^{7}$, PÉTER SPAKOVSZKY ${ }^{7}$, JOCHEN STEINDL ${ }^{7}$

\author{
${ }^{1}$ I. Meštrovića 74, HR-31326 Darda, CROATIA \\ ${ }^{2}$ Vatroslava Lisinskog 3, HR-31500 Našice, CROATIA \\ ${ }^{3}$ Institute of Ornithology, Croatian Academy of Sciences and Arts, \\ Gundulićeva 24, HR-10000 Zagreb, CROATIA \\ ${ }^{4}$ Department of Biology and Wildlife Diseases, \\ Faculty of Veterinary Hygiene and Ecology, \\ University of Veterinary and Pharmaceutical Sciences Brno, \\ Palackého tř. 1, 61242 Brno, CZECH REPUBLIC \\ ${ }^{5} 68713$ Březolupy 324, CZECH REPUBLIC \\ ${ }^{6}$ Nature Conservation Agency of the Czech Republic, Regional Office Brno, \\ Kotlářská 51, 60200 Brno, CZECH REPUBLIC \\ 7 Technisches Büro für Biologie, Quadenstrasse 13, \\ 2232 Deutsch-Wagram, AUSTRIA
}

e-mail: tomikadrian@gmail.com; jledinscak@yahoo.com; dora.dvorzak@gmail.com; jkralj@hazu.hr; literaki@vfu.cz; stanislav.vyhnal@seznam.cz; hynekmb@centrum.cz; david.horal@seznam.cz; rainer.raab@tbraab.at; peter.spakovszky@tbraab.at; jochensteindl@tbraab.at 


\begin{abstract}
Until 2018 the Red Kite was considered a regionally extinct breeding species in Croatia and a rare winter visitor in Eastern Slavonia. This paper provides an overview of the results of a satellite telemetry study of Red Kites tagged in Austria, Slovakia and the Czech Republic. This is the first comprehensive study on the phenology of the species in Croatia. Between September 2014 and October 2018, a total of 39 tagged individuals have been recorded in Croatia and spent a collective total of 1484 days here. Red Kites mainly occurred in Croatia from September to March, while few birds remained here during the summer. Birds nesting in central Europe migrate through Croatia in broad front, appearing in all parts of the country, moving SW to wintering grounds in Italy, while fewer individuals follow the SE direction to Greece. Furthermore, the wintering behaviour of four tagged Red Kites were recorded using communal roosts in the continental part of Croatia. During the early spring of 2018, a female Red Kite tagged in the Czech Republic was suspected of breeding in Eastern Slavonia and later in the season the nesting was confirmed south of the town of Đakovo, even though it was unsuccessful.
\end{abstract}

Keywords: Red Kite, Croatia, satellite telemetry, nesting, phenology.

\title{
INTRODUCTION
}

The Red Kite Milvus milvus is an opportunistic raptor inhabiting a mosaic of habitats including fragmented forests and open land which it uses for breeding and roosting. It is essentially a European species, and outside of Europe it is found only scattered in North Africa (Birdlife International 2019). The Western Palearctic population totals (and of the world) between 25,000 and 33,000 breeding pairs, with Germany, Switzerland, France, and Spain being the most important areas for its occurrence accounting for approximately $90 \%$ of the world population (Génsbøl \& Thiede 2008, Birdlife International 2015). The eastern Red Kite population is much smaller with $28-35$ breeding pairs in Austria (an estimate for 2011 - 2012), around 175 pairs in the Czech Republic (an estimate for 2012), approximately 13 pairs in Slovakia and 13-15 pairs in Hungary (an estimate for 2017) (Rak 2013, Birdlife International 2015, Maderič \& Svetlík 2016, DemeTER et al. 2017). In eastern Europe, the Red Kite breeds sporadically in a limited number of pairs (3-10 pairs in Belarus, 1-10 pairs in Ukraine, 1-6 pairs in Russia, and likely no breeding pairs in Romania and Bulgaria) (BIRDLIFE INTERNATIONAL 2015). Due to the moderately rapid population decline, the Red Kite is globally Near Threatened (BirdLife InTERnational 2019).

Prior to 2018 the Red Kite was considered to be an extinct breeding species in Croatia. Formerly, it had nested in the eastern part of lowland Croatia (Baranja and Eastern Slavonia), and the last recorded breeding event occurred in 1968 
near to the village of Migalovci (BARIšić 2013). Recently, no breeding pairs have been recorded there (Birdlife InTERnational 2019) and, according to the Croatian Red Data Book, it is an irregular species during the migration and wintering periods (BARIšrć 2013). Recent field observations suggest that the Red Kite is a regular migrant throughout the whole of Croatia and a regular wintering species in Baranja and Eastern Slavonia (IWC Croatia 1967 - 2018; Archives of Croatian Society for Birds and Nature Protection).

In 2014, the ecology of Red Kite populations in Austria, Czech Republic and Slovakia began to be studied using telemetry (RAAB et al. 2017). Some of these tagged individuals occurred in Croatia and therefore we were able to describe the spatiotemporal distribution of Red Kites in the country.

Due to the limited scientific knowledge regarding the Red Kite in Croatia, the aim of this paper is to provide detailed information regarding its occurrence using tracking data. Information about Red Kites in Croatia can be helpful from a pan-European point of view in protecting this near-threatened raptor species.

\section{MATERIALS AND METHODS}

From 10 July 2014 until 31 March 2018, a total of 95 Red Kite pulli were fitted with telemetry devices on nests in the Czech Republic (61 birds), Austria (26 birds) and Slovakia ( 8 birds). Some of these birds ( 24 from the Czech Republic, 11 from Austria and 4 from Slovakia) were subsequently found to be using Croatian territory during parts of their life cycle.

Saker H loggers ( $20 \mathrm{~g}$; Ecotone, Sopot, Poland) were used to track the birds. The loggers were fitted onto the backs of the birds using harnesses (backpack) with $6 \mathrm{~mm}$ Teflon ribbon encircling the body by two loops around the bases of the wings and joined in front of the breastbone. The loggers work in GPS (global position system)/GSM (global system for mobile communication) systems or in GPS/GSM/UHF (ultra-high frequency). GPS positions of the birds were collected according to individual settings (1 position fixed every $5 \mathrm{~min}$ to $6 \mathrm{~h}$ ) and were sent by SMS (short message service) via local mobile telephone operators to the Ecotone Center in Poland, where they were saved and archived, or data were uploaded by receivers locally and again saved and archived. GPS/GSM positional data were transformed into tracks on a map in order to visualize the spatiotemporal activities of the tagged birds. Subsequent positions were connected by a line using a GIS (geographic information system), specifically the software packages ArcGIS, QGIS and ESRI Basemaps (ESRI Global Inc., USA, www.qgis.org). This software was also used for GIS analyses and for map visualization. The sex of birds was determined by DNA analysis of juvenile feather samples (SUH et al. 2011).

We analysed the data for the period of time each Red Kite spent in Croatia, and we counted the number of days per month during which each bird stayed in Croatia. We also determined the locations used by each bird as points localized 
by GPS. Using combined temporal and spatial data, we determined the most attractive areas and time periods in Croatia for Red Kites.

Moreover, we described the breeding phenology and ecology of a Red Kite tagged with telemetry logger, based on telemetry data analysis and field observations. The nesting ecology and the breeding success were investigated by field survey conducted on three occasions between April and June 2018. The field survey included: direct observations of behaviour of the Red Kite pair in the nesting territory, locating the nest and in situ checking of the nest by a climber.

\section{RESULTS}

\section{Spatiotemporal data about occurrence of Red Kites in Croatia}

We found 39 individual Red Kites occurring in Croatia from 15 September 2014 until 15 October 2018, these birds stayed in Croatia for a total of 1484 days (Table 1). The birds occurred in Croatia mainly in the period from September to March, with peak occurrences in October (Figure 1). The occurrences from April to July refer mostly to immature non-breeding birds but can also indicate possible breeding as was confirmed in the case of female C144030 in eastern Croatia. It became evident from the data that Red Kites originating from the central European breeding population are regularly crossing Croatia during the autumn and spring migration and some of them are also wintering in the country.

Table 1. Monthly and annual numbers of bird/day stay of all satellite-tagged Red Kites occurring in Croatia.

Tablica 1. Mjesečni i godišnji brojevi zadržavanja ptica po danu svih crvenih lunja zabilježenih u Hrvatskoj na temelju satelitskog praćenja.

\begin{tabular}{|l|c|c|c|c|c|c|}
\hline & $\mathbf{2 0 1 4}$ & $\mathbf{2 0 1 5}$ & $\mathbf{2 0 1 6}$ & $\mathbf{2 0 1 7}$ & $\mathbf{2 0 1 8}$ & SUM \\
\hline January & 0 & 18 & 31 & 93 & 31 & $\mathbf{1 7 3}$ \\
\hline February & 0 & 16 & 29 & 99 & 28 & $\mathbf{1 7 2}$ \\
\hline March & 0 & 0 & 31 & 90 & 44 & $\mathbf{1 6 5}$ \\
\hline April & 0 & 0 & 13 & 12 & 31 & $\mathbf{5 6}$ \\
\hline May & 0 & 0 & 30 & 3 & 33 & $\mathbf{6 6}$ \\
\hline June & 0 & 0 & 13 & 8 & 8 & $\mathbf{2 9}$ \\
\hline July & 0 & 0 & 0 & 10 & 0 & $\mathbf{1 0}$ \\
\hline August & 0 & 3 & 1 & 0 & 0 & $\mathbf{4}$ \\
\hline September & 2 & 65 & 33 & 31 & 25 & $\mathbf{1 5 6}$ \\
\hline October & 25 & 40 & 111 & 72 & 26 & $\mathbf{2 7 4}$ \\
\hline November & 30 & 34 & 98 & 34 & 0 & $\mathbf{1 9 6}$ \\
\hline December & 31 & 31 & 90 & 31 & 0 & $\mathbf{1 8 3}$ \\
\hline & $\mathbf{8 8}$ & $\mathbf{2 0 7}$ & $\mathbf{4 8 0}$ & $\mathbf{4 8 3}$ & $\mathbf{2 2 6}$ & $\mathbf{1 4 8 4}$ \\
\hline
\end{tabular}




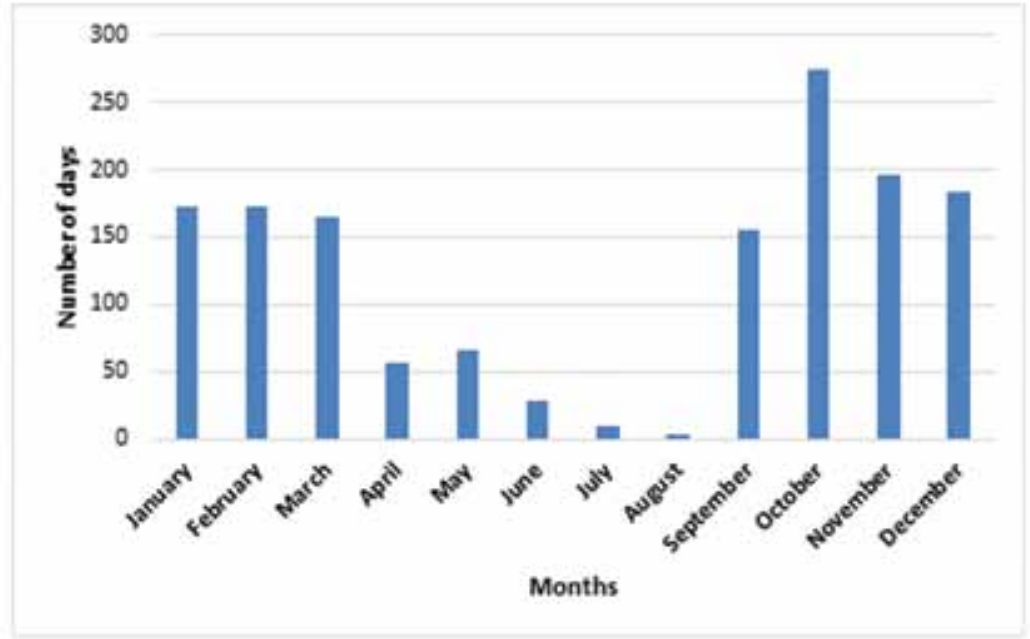

Figure 1. Dynamics of the annual occurrence in Croatia of Red Kites Milvus milvus from central European breeding population (CZ, SK, AT). Numbers of days were counted as number of one bird/one day stays, 2014-2018, cumulative data.

Slika 1. Sezonska dinamika pojavljivanja crvenih lunja u Hrvatskoj porijeklom iz srednjoeuropske gnijezdeće populacije (CZ, SK, AT). Broj dana predstavlja kumulativan zbroj boravka jedne ptice po danu za sve ptice u razdoblju 2014.-2018.

Most of the Red Kites that occurred in Croatia originated from the breeding population located on the tripoint border area of Austria, Slovakia and the Czech Republic. Two of these birds originated from the eastern Slovakian and one from southern Czech subpopulations (Figure 2). Red Kites that migrated from breeding grounds in central Europe crossed Croatia in broad front, with occurrences recorded across the country (Figure 3), including many islands as well, even the remote ones (e.g. Vis, Lastovo and others). These birds migrated through Croatia relatively fast and usually stayed for only a couple of days before crossing the Adriatic Sea and reaching their main wintering grounds in Italy. They migrated in a SSW direction through Austria, Hungary, Croatia, Slovenia, and Bosnia and Herzegovina using the Adriatic flyway. Some of the birds crossing Croatia followed the eastern Adriatic coastline in a SE direction, reaching their wintering places in Greece (Figure 4).

During the period from 2014 to 2018 (four wintering periods), only four tagged Red Kites (three from CZ and one from SK) were found overwintering in the continental part of Croatia: two birds in eastern Croatia (Jagodnjak and Punitovci villages), one in the central Sava valley (Sičice village) and one in western Croatia (Donja Zdenčina village) (Figure 2). Three birds spent only a single winter in Croatia, while one bird spent three consecutive winters in the country. 
During the autumn months, birds arrived at their wintering grounds in Croatia between 5 Sep and 9 Nov (median 7 Oct), whereas the spring departure period ranged from 14 Feb until 5 April (median 10 March). The median arrival and departure dates coincided with the peak autumn and spring migration period of Red Kites in Croatia. During the winter periods (Nov-Feb) regular field visits

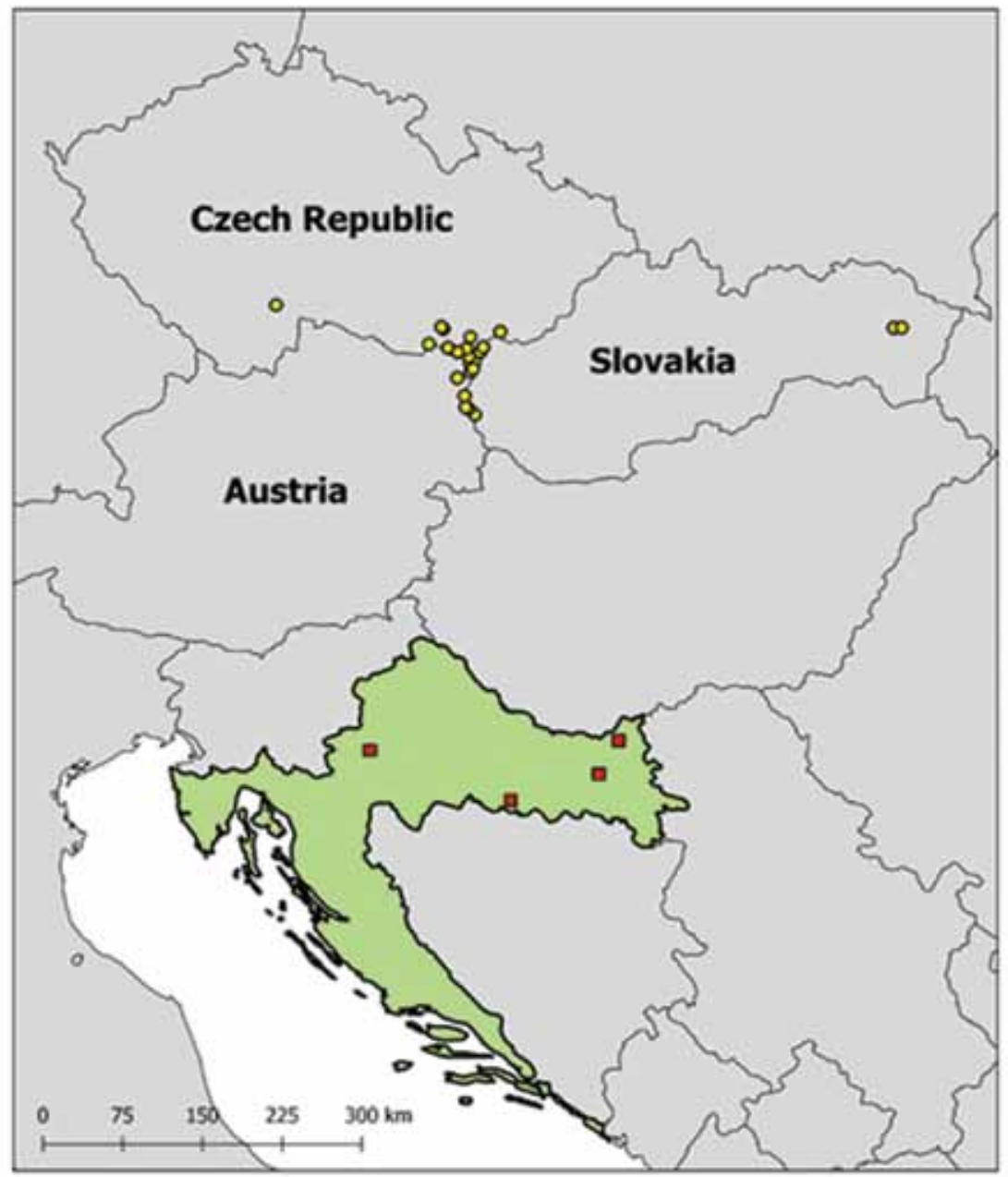

Figure 2. Breeding and wintering places of Red Kites occurring in Croatia (2014-2018). Yellow circles - nests of all satellite-tagged Red Kites that then stayed at least one day in Croatia; red square - wintering sites of Red Kites originating from central European breeding population (CZ, SK, AT) (map: S. Vyhnal).

Slika 2. Mjesta gniježđenja i zimovanja crvenih lunja koje se pojavljuju u Hrvatskoj (2014.2018.). Žuti krugovi - položaj gnijezda svih označenih crvenih lunja koje su u Hrvatskoj boravile barem jedan dan; crveni kvadrati - mjesta zimovanja crvenih lunja porijeklom iz srednjoeuropske gnijezdeće populacije (CZ, SK, AT) (karta: S. Vyhnal). 
were conducted on the roosting places of tagged Red Kites. It was found that Red Kites spend the night gathering in smaller groups (3-13 ind.) in communal roosting places (tree-lines, forest patches, edges of larger forests). The habitat of roosting and wintering places was comprised of lowland agricultural landscapes with small fields and meadows, small to medium-sized forest patches and small villages (in one case with a nearby waste dump). On the two roosting places in eastern Croatia a sympatric wintering of Red Kites and Black Kites Milvus mi-

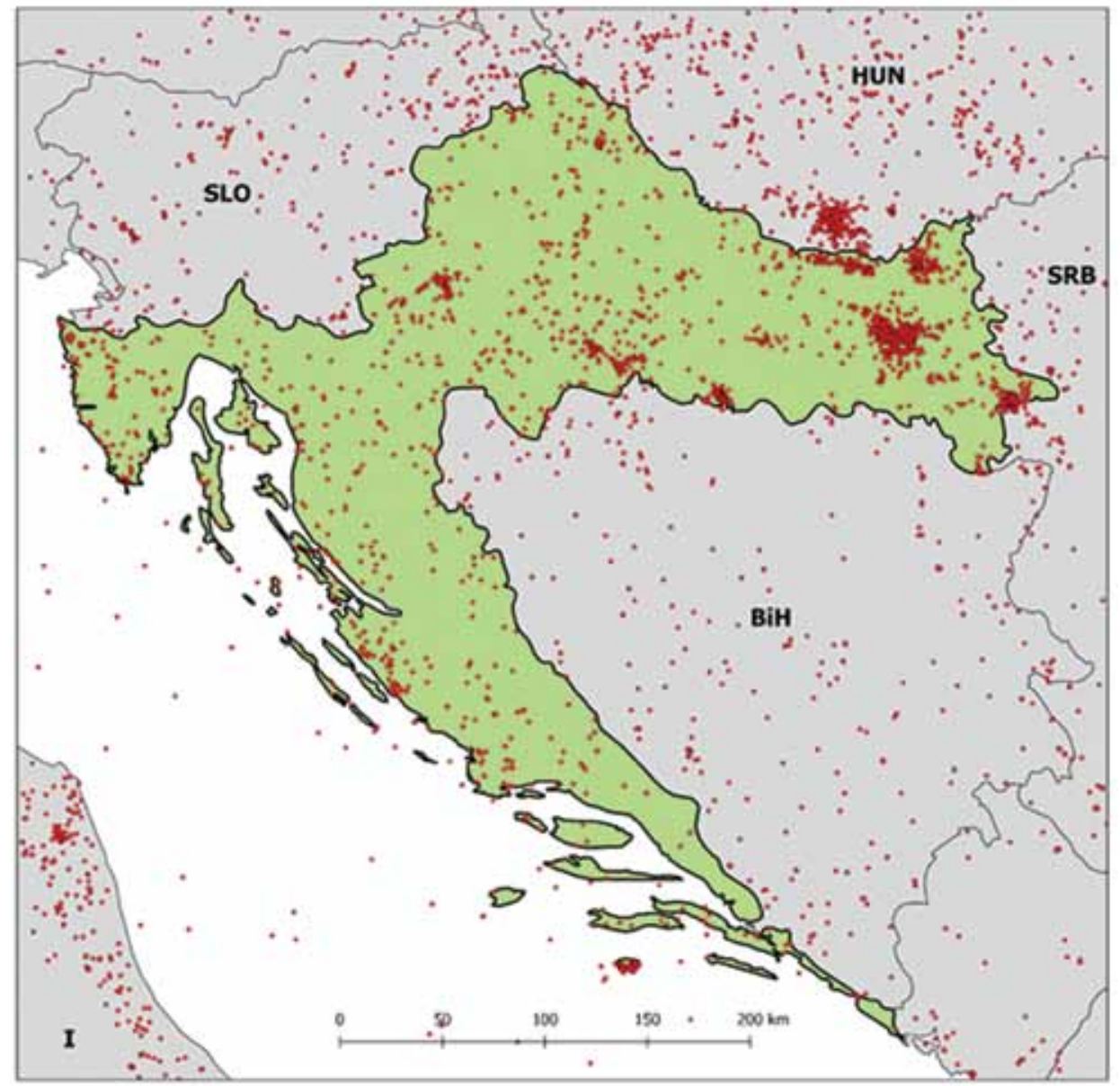

Figure 3. Occurrence of Red Kites in Croatia originating from central European breeding population (CZ, SK, AT). The red dots represent all positions of tagged Red Kites that stayed at least one day in Croatia (2014-2018) (map: J. Steindl).

Slika 3. Rasprostranjenost crvenih lunja u Hrvatskoj porijeklom iz srednjoeuropske gnijezdeće populacije (CZ, SK, AT). Crvene točke označavaju mjesta gdje su označene crvene lunje boravile barem jedan dan (2014.-2018.) (karta: J. Steindl). 
grans was recorded. Based on this study of tagged birds, it became clear that lowland areas throughout eastern Croatia are the most important wintering places for Red Kites in the country.

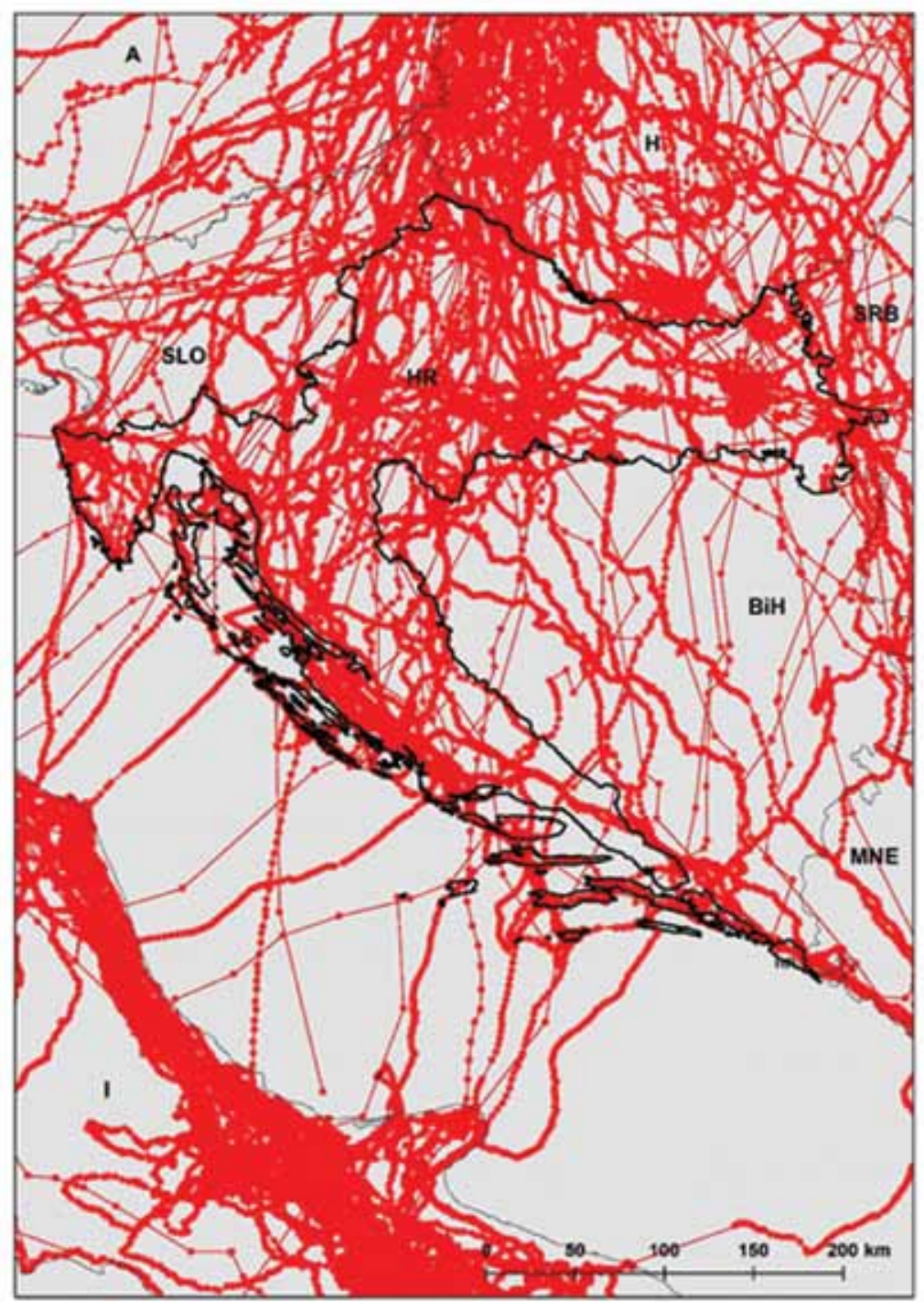

Figure 4. Occurrence of tagged Red Kites during their stays in Croatia. Circles depict the positions of birds. Every line connects successive GPS positions of a bird (2014-2018) (map: J. Steindl).

Slika 4. Pojava označenih crvenih lunja tijekom boravka u Hrvatskoj. Krugovi prikazuju položaje ptica. Svaka linija povezuje uzastopne GPS položaje ptice (2014.-2018.) (karta: J. Steindl). 


\section{Breeding of Red Kites in Croatia in 2018}

Breeding of the Red Kite in Croatia was observed in 2018 nearby Novi Perkovci village, Đakovo, eastern Slavonia. A female bird (C144030) from the pair was tagged and the nest was found based on behavioural patterns obtained through satellite telemetry data. Bird C144030 was found as a chick in the nest with a dead adult female (suspected illegal shooting) on 16 June 2016 near Pouzdřany in the Czech Republic, rescued and later tagged and released on 23 July 2016 in the vicinity of Břeclav in the Czech Republic.

The bird wintered in Italy for two consecutive winters in between which it returned to the Czech Republic during the summer and autumn months (Figure 5). During the migration period, it regularly crossed western Croatia, northern Dalmatia and the Adriatic Sea. After the second winter in the spring of 2018, while returning from the wintering site, it stopped for a longer time nearby Novi Perkovci.

On the 9th April, Josip Ledinšćak and Dora Dvoržak visited the location and on the edge of a mid-aged oak-hornbeam forest they noticed and photographed a pair of Red Kites performing territorial behaviour. The satellite transmitter was clearly visible on the back of the female, however the male was untagged. The two birds were repeatedly flying to the same place in the canopy at the edge of the forest, and the typical breeding call of the male was recorded while it chased away a Common Buzzard Buteo buteo.

In May 2018, the GPS positions of the female clearly suggested that incubation was taking place and the bird spent most of the time within a 100-metre diameter at the edge of the forest. On May 7, the first three authors visited this location and found the nest approximately $15 \mathrm{~m}$ high on an English Oak Quercus robur near to the forest edge. The female was sitting in the nest and then flushed but soon afterwards she was observed circling above the area with her mate. The male was observed carrying a rodent which appeared to be a Brown Rat Rattus norvegicus.

In the beginning of June, the behaviour of the female suddenly changed. On June 2 the female left her nest for circa $11 \mathrm{~km}$ NE but returned. On June 4 she left again and then again on June 5 ( $8 \mathrm{~km} \mathrm{NE}$ and $9 \mathrm{~km}$ ENE, respectively). On June 6 she abandoned the nest and began a journey to the Czech Republic crossing Serbia, Hungary and Slovakia along the way. The night from 6th to 7th June she had already travelled approximately $117 \mathrm{~km}$ NE from the nest near Bácsbokod, Hungary. On 7 June, the nest was checked in-situ by a climber. There were only a few feathers and one cracked Red Kite egg on the nest. Moreover, small white droppings were observed in and under the nest. No prey remains were found. The male was circling nearby but at this point, the female was nearing the border between Hungary and Slovakia some $270 \mathrm{~km}$ away.

The female spent the rest of the summer in the Czech Republic where she stayed in a similar area as in 2017. She also appeared in a temporary roosting 
location where individuals of both kite species were observed. On 24 September 2018 she set out to winter in Italy once again where she arrived on 30 September and stayed there until 15 October 2018 (Figure 5).

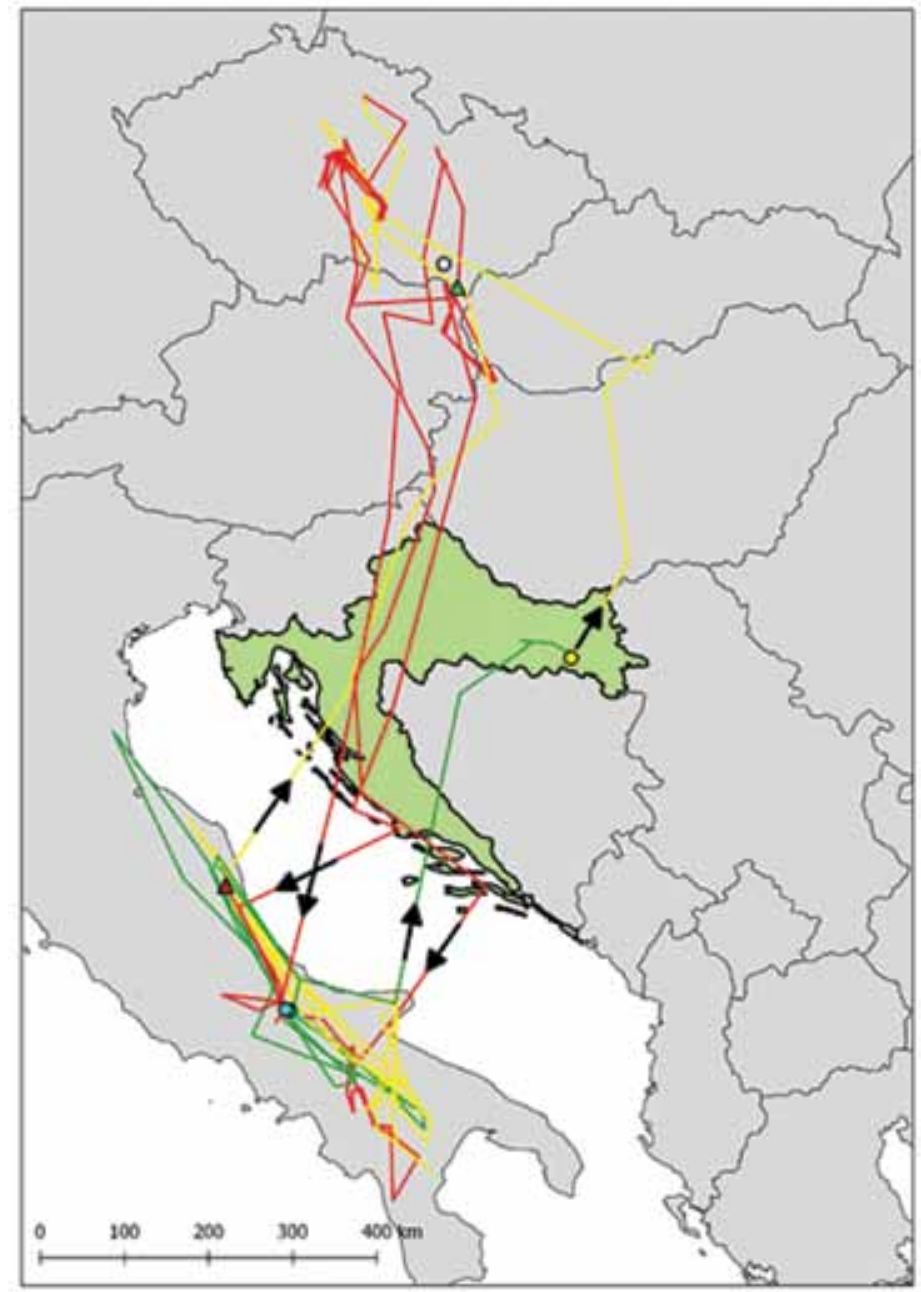

Figure 5. Movement of female Red Kite C144030. Empty circle - nest in 2016; green triangle - place of release; red line - movement in post-breeding migration; blue circle - wintering site (December, January); green line - spring migration; yellow line - movement in the period of summer vagrancy (May, June); yellow circle - nest in 2018; red triangle - position on 15 October 2018 (map: S. Vyhnal).

Slika 5. Kretanje ženke crvene lunje C144030. Prazan krug - mjesto izlijeganja; zeleni trokut - mjesto puštanja; crvena linija - jesenska selidba: plavi krug - mjesto zimovanja (prosinac-siječanj); zelena linija - proljetna selidba; žuta linija - ljetno lutanje (svibanjlipanj); žuti krug - mjesto gniježđenja tijekom 2018.; crveni trokut - položaj ptice na dan 15. listopada 2018. (karta: S. Vyhnal). 


\section{DISCUSSION}

\section{Spatiotemporal data}

Whereas southern European Red Kite populations are resident, most of the northern European birds tend to migrate wintering around the Mediterranean, with some flying on to North Africa and Turkey (Génsbøl \& Thiede 2008, Kirvan et al. 2008). Interestingly, in the past 25 years an increasing proportion of the population in Sweden, Germany, Switzerland and France has spent the winter close to or within the breeding range (GÉnsbøl \& THIEDE 2008). This has always been the case for the small population in central Wales (Davis \& Newton 1981). This tendency is possibly due to milder winters in recent decades and perhaps also to the greater food availability.

Croatia is an important wintering place for Red Kites from the central European population (LiтERÁк et al. 2019, this study). In some parts of central Europe, the population density is now slowly increasing. In the Czech Republic, for example, the Red Kite recolonized the country after around 100 years of absence and breeding was confirmed for the first time in 1976 (Šřastný et al. 2006). Since then, the population has expanded to 30-50 breeding pairs in 1985-1989, 70-100 breeding pairs during $2001-2003$, and to approximately 125 breeding pairs at present (BirdLIFE InTERNATIONAL 2004, ŠŤASTNÝ et al. 2006, RAK 2013).

Wintering of Red Kites in Baranja has been recorded since 2002 (BARIšić 2013) but exact data are scarce. In 2002, at least two Red Kites wintered in the Croatian Baranja (BARIšIć 2013). Recently, counts of Red Kites taken between 21st January 2015 and 22nd January 2017 revealed wintering of 7-11 Red Kites in eastern Croatia (Jagodnjak and Punitovci) together with one Black Kite in 2015 (LiтеRÁк et al. 2017, I. Literák, R. Petro and H. Matušík unpublished observations).

During the winter of 2017/18 an important roosting site for Red Kites was discovered with the help of telemetry tracking in an adjacent area of the Hungarian Baranya, with 37 Red Kites and 2 Black Kites counted on 6 Jan 2018 (D. LAczIK unpublished observations) and recently most of the breeding territories within Hungary have been located there (Dudás 2014, Mórocz et al. 2015, NAGy et al. 2016).

In Serbia (bordered by Croatia and Hungary including Baranja/Baranya), Red Kites also stopped to nest in the second half of the 20th century (RAŠAJSKI J. \& MARINKović S. 2000). Based on telemetry tracking it was revealed that in Serbia, Red Kites occurred mostly in the western part of Vojvodina Province, close to the Serbian-Croatian border. They were recorded most often in April and October, which corresponded to their spring and autumn migrations, respectively (Literák et al. 2018).

It now appears that Red Kites occur in the southern part of the Pannonian Basin, including Baranja (Croatia), Baranya (Hungary) and western Vojvodina (Serbia) more frequently than in the second half of the 20th century. This is not 
only based on our results but also according to some direct observations (ŠćiBAN et al. 2015, KovÁts et al. 2016, A. Tомıк unpublished observations). This lowland area is characterised by agricultural landscapes with small fields and meadows, small to medium-sized forest patches and small villages which provide suitable habitats for Red Kites.

We can speculate that as the density of Red Kites in central Europe continues to increase, the wintering of Red Kites in Croatia will occur more often than in the past. In the area of Baranja and eastern Slavonia, the Red Kite could become a regular nesting species in the future as demonstrated by our record of a new breeding event in eastern Croatia during 2018. Vagrant young Red Kites originating from Austria, the Czech Republic, Slovakia and Hungary which migrate through Croatia could provide a base for the next breeding population in this area, which has landscape characteristics suitable for breeding Red Kite populations. This situation has been observed in Switzerland where since the discovery of the first roosts of wintering Red Kites in 1970, the numbers of wintering and nesting birds has steadily increased (Aebischer 2009).

\section{Breeding}

The new breeding site near Đakovo is situated some $30 \mathrm{~km}$ east from the last known breeding site in the Požeška Kotlina area (Migalovci village) and about 50 $\mathrm{km}$ south from the other historic breeding area in Baranja (Čeminac and Bilje villages) (Mikuska et al. 2002, BARIšić 2013). Even though 50 years have passed since the last known breeding of Red Kites in Croatia, it seems that eastern Croatia remains the most important region for the nesting of the species in the country. It is evident that the habitat conditions and the food supply are still favourable for Red Kites and possibly other, yet undiscovered pairs already exist in some parts of this region.

Based on data from our tracking devices, female breeding activities last for many days, and while incubation in that species lasts 30 days (HaraszTHy 1998), we assume that at least one chick hatched and was possibly predated, as no signs of it were found in the nest. The presence of chick(s) is very probable according to small (fine) droppings observed under the nest. The Red Kite egg found in the nest may have been infertile and the crack on the egg may be a result of predation.

The female C144030 was a two-year old breeding bird, which is not so uncommon in this species. In Wales Red Kites breed for the first time at 2-7 years old (mean 3.6), most of them at the age of 2-4 years (Newton et al. 1989). The mean age of first breeding in England (1.85) and Scotland (2.15) was even lower (Evans et al. 1999).

Although the Red Kite pair did not raise any chicks in 2018, the first known nesting of the species after an absence of 50 years was undoubtedly confirmed. Of the neighbouring countries, the Red Kite breeds in Austria and Hungary 
(BirdLife International 2019). The closest population to eastern Slavonia is the Hungarian population, with 13-15 pairs breeding in the southwestern part of Hungary where the population trend has slowly increased in the last decade (Demeter et al. 2017). Since this population is partly situated relatively close to the Hungarian-Croatian border, searching the areas on the Croatian side for new Red Kite territories is recommended in the future.

The breeding habitat of Red Kites in Croatia in 2018 was similar to that in other countries in central Europe. Nesting places were the same as in Baranya (Hungary) where the Red Kite prefers lowland oak-hornbeam forests (HARAszTHY 1998).

Additionally, a pair of Black Kites Milvus migrans also bred in the same forest in close vicinity (most probably 100-200 m) to the Red Kite nest. Similar observations of close breeding of these two species have been known from other areas of Europe too (HorÁK 2002).

\section{Acknowledgements}

We would like to thank Miloš Martinović, Tomica Rubinić (HR), Karel Makoň, Jakub Mráz, Lubomír Peške (CZ), Boris Maderič, Štefan Mikiara, Vladimír Pečeňák, (SK) for their cooperation and help during the fieldwork. We thank Connor Panter for the English language editing.

\section{References}

Aebischer, A. (2009): Migration and wintering of Swiss Red Kites assessed by satelite telemetry. pp. 48-51. In: David F. (ed.): Proceedings of the Red Kite International Symposium, October 17-18, 2009, Montbéliard, France. - LP Mission Rapaces and LPO Franche-Comté, Paris, France.

BARIšIć, S. (2013): Crvena lunja Milvus milvus Linnaeus, 1758. pp 75-76 In: Tutiš, V., Kralj, J., Radović D., Ćiković D., Barišıć, S. (eds): Crvena knjiga ptica Hrvatske [Red Data Book of birds of Croatia]. Ministarstvo zaštite okoliša i prirode, Državni zavod za zaštitu prirode, Zagreb.

Birdlife InTERnational (2004): Birds in Europe: population estimates, trends and conservation status. Cambridge, UK: BirdLife International (Conservation Series No. 12)

Birdlife International (2015): European Red List of Birds. The IUCN Red List of Threatened Species. Luxembourg: Office for Official Publications of the European Communities. 75 pp.

BirdLife International (2019): Species factsheet: Milvus milvus. Downloaded from http://www.birdlife.org on 09/07/2019.

Davis, P.E., Newton, J.E. (1981): Population and breeding of Red Kites in Wales over a 30-year period. Journal of Animal Ecology 50: 759-772.

Demeter I., Horváth M., Prommer M. (2017): Az MME Ragadozómadár-védelmi Szakosztálya (RMvSz) által monitorozott fajok 2017-es költési eredményeinek összefoglalása. Heliaca 15: 74-75. 
Dudás, M. (2014): A vörös kánya (Milvus milvus) európai elterjedési (fészkelési) viszonyai és a magyarországi állományának fenntartási lehetősége [(Breeding) distribution of the red kite (Milvus milvus) in Europe and the possibility to maintain the Hungarian population]. Heliaca 12: 55-65. [in Hungarian, with English summary]

Evans, I.M., Summers, R.W., O’Toole, L., OrR-Ewing, D.C., Evans, R., Snell, N., Smith, J. (1999): Evaluating the success of translocating Red Kites Milvus milvus to the UK. Bird Study 46:129-144.

Génsbøl, B., Thiede, W. (2008): Collins Birds of Prey. HarperCollins Publishers, London, $\mathrm{UK}, 416 \mathrm{pp}$.

HoRÁк, P. (2002): Hnízdění luňáka hnědého (Milvus migrans) a luňáka červeného (Milvus milvus) na jižní Moravě v letech 1991 - 2000 [Nesting of black kite (Milvus migrans) and red kite (Milvus milvus) in South Moravia in 1991-2000]. Crex - Zpravodaj Jihomoravské pobočky ČSO 18: 9-20. [in Czech, with English summary]

Kirvan, G.M., Boyla, K.A., Castell, P., Demirci, B., Özen, M., Welch, H., Marlow, T. (2008): The Birds of Turkey. The Distribution, Taxonomy and Breeding of Turkish Birds. Christopher Helm, London, UK, 512pp.

Kováts, L., Bank, L., Mórocz, A., Orbán, A., VÁczi, M., Haraszthy, L. (2016): A vörös kánya (Milvus milvus) magyarországi helyzete 2016-ban [The status of the red kite (Milvus milvus) in Hungary in 2016]. Heliaca 14: 50. [in Hungarian, with English summary]

Literák, I., Horal, D., Alivizatos, H., Matušík H. (2017): Common wintering of Black kites (Milvus migrans migrans) in Greece, and new data on their wintering elsewhere in Europe. Slovak Raptor Journal 11: 91-102.

Literák, I., RaAb, R., Vyhnal, S., Spakovszky, P., Steindl, J. (2018): Occurrence of Red Kites Milvus milvus in Serbia based on birds tracked by telemetry devices. Acrocephalus 39 (176/177): 27-32.

Literák, I., Horal, D., RaAb, R., Matušík, H., Vyhnal, S., Rymešová, D., Spakovszky, P., Skartsi, T., Poirazidis, K., Zakkak, S., Tomik A., Skyrpan, M. (in press): Sympatric wintering of Red Kites and Black Kites in south-east Europe. Acta Zoologica Academiae Scientiarum Hungaricae 65: 381-398.

Maderič, B., Svetlík, J. (2016): Správy pracovných skupín za rok 2015: Haja červená (Milvus milvus). Birds of Prey and Owls - Journal of Raptor Protection of Slovakia 12 (1): 19-20.

Mikuska, J., Mikuska, T., Romulić, M. (2002): Ptice, Vodič kroz biološku raznolikost Kopačkog rita. Matica hrvatska, Osijek.

Mórocz, A., Bank, L., Kováts, L., Orbán, A., Váczi, M., Haraszthy, L. (2015): A vörös kánya (Milvus milvus) magyarországi helyzete 2015-ben [The status of the red kite (Milvus milvus) in Hungary in 2015]. Heliaca 13: 39. [in Hungarian, with English summary]

Nagy, Z., Nagy, K., Horváth, M., Orbán, Z. (2016): Elkészült a 2016. évi XIII. Országos Sasleltár [The complete results of XIIIth countrywide eagle count 2016]. www.mme. hu/elkeszult-2016-evi-xiii-orszagos-sasleltar (accessed 29 January 2016) [in Hungarian] 
Newton I., Davis, P.E. \& Davis, J.E. (1989): Age of first breeding, dispersal and survival of Red Kites Milvus milvus in Wales. Ibis 131:16-21.

RaAb, R., Literák, I., Schütz, C., Spakovszky, P., Steindl, J., Schönemann, N., Tarjányi, S. G., PešKe, L., Makoň, K., Mráz, J., Maderič, B., Pečeňák, V., Matušík H., Schulze, C.H. (2017): GPS-basierte Telemetriestudien an mitteleuropäischen Rotmilanen Milvus milvus - methodische Schwierigkeiten und analytische Möglichkeiten basierend auf ersten Ergebnissen. Ornithologische Mitteilungen 69: 245-260.

RAK, D. (2013): Luňák červený (Milvus milvus). Zpravodaj Skupiny na ochranu a výzkum dravců a sov 13: 36-38.

RAšAJSki J., Marinković S. (2000): Crvena lunja Milvus milvus (Linnaeus, 1758). pp. 45-50 In: Puzović S. (ed.): Atlas ptica grabljivica Srbije, mape rasprostranjenosti i procene populacija 1977 - 1996. - Závod na zaštitu prirode Srbije, Beograd.

Šćiban M., Rajković D., Radišić D., Vasić V., PAntović U. (2015): Birds of Serbia - Critical List of Species. - Institute for Nature Conservation of Vojvodina Province and Bird Protection and Study Society of Serbia, Novi Sad.

ŠŤAstnÝ K., BeJČEK, V., Hudec, K. (2006): Atlas hnízdního rozšíření ptáků v České republice 2001-2003. Aventinum, Praha, 463 pp.

Suh, A., Kriegs, J.O., Brosius, J., Schmitz, J. (2011): Retroposon insertions and the chronology of avian sex chromosome evolution. Mol Biol Evol 28: 2993-2997.

\section{SAŽETAK}

Crvena lunja nastanjuje otvorena mozaična staništa zapadnog palearktika s najvažnijim gnijezdećim populacijama u Njemačkoj, Švicarskoj, Francuskoj i Španjolskoj. Prema istoku Europe brojnost parova postaje sve manja. U Hrvatskoj se sve do 2018. godine smatrala regionalno izumrlom gnjezdaricom te rijetkom zimovalicom istočne Slavonije i Baranje. Ranije se gnijezdila na istoku Hrvatske, a posljednje gniježđenje je zabilježeno 1968. godine kod Migalovaca. Nakon što je 2014. godine u Austriji, Slovačkoj i Češkoj pokrenut projekt praćenja crvenih lunja pomoću GPS/GSM i GPS/GSM/UHF uređaja, pokazalo se da mnoge od njih zalaze i u Hrvatsku. Ovaj rad daje kratak pregled rezultata dobivenih analizom podataka sa satelitske telemetrije. U razdoblju od rujna 2014. do listopada 2018.g. u Hrvatskoj je zabilježeno 39 različitih crvenih lunja označenih uređajima za praćenje te su ovdje provele sveukupno 1484 dana. Glavni period pojavljivanja crvenih lunja u Hrvatskoj je od rujna do ožujka (s vrhuncem selidbe u listopadu odnosno ožujku), dok se malobrojne ptice ovdje zadržavaju i tijekom ljetnog lutanja. Ptice koje gnijezde u srednjoj Europi kroz Hrvatsku sele u širokom pojasu, pojavljujući se u svim dijelovima zemlje pa čak i na nekim pučinskim otocima, prateći osnovni smjer JJZ do zimovališta u Italiji, dok manji broj jedinki seli u smjeru JI i zimuje u Grčkoj. Između 2014. i 2018. zabilježeno je zimovanje četiri označene crvene lunje u Hrvatskoj (po jedna ptica u Baranji, istočnoj Slavoniji, srednjoj Posavini i Pokupskom bazenu), s dolaskom na zimovališta većinom u 
listopadu i odlaskom oko sredine ožujka. Terenski obilasci su pokazali da se tijekom zime crvene lunje $u$ manjim skupinama (3-13 jed.) okupljaju na redovito korištenim noćilištima (šumarci, drvoredi i sl.) te je na dva mjesta utvrđeno zajedničko noćenje s crnim lunjama Milvus migrans. Tijekom ranog proljeća 2018. godine jedna od crvenih lunja zadržavala se u istočnoj Slavoniji južno od Đakova te se sumnjalo na mogući pokušaj gniježđenja. Radilo se o mladoj ženki s uređajem AUKI49 označenoj kao ptić prstenom C144030 tijekom 2016. godine u okolici Břeclava u Češkoj, nakon čega je u dva navrata zimovala u Italiji i redovito selila preko Hrvatske. Obilaskom terena u travnju opaženo je svadbeno ponašanje ženke i mužjaka crvene lunje bez oznake, dok je u svibnju na istom mjestu na rubu šume hrasta i graba pronađeno gnijezdo na hrastu lužnjaku i ženka koja je sjedila u njemu. Početkom lipnja tijekom provjere gnijezda nisu pronađeni mladi, već samo nekoliko pera i jedno napuklo jaje crvene lunje. Mužjak je uočen iznad šume dok je ženka netom prije napustila područje i uputila se prema Češkoj. Na temelju analize uzorka kretanja ženke tijekom proljeća odnosno činjenica utvrđenih terenskim obilascima, pretpostavlja se da se u gnijezdu najmanje jedan ptić uspješno izlegao te da je vjerojatno postao žrtvom predacije. Iako tijekom 2018.godine par crvenih lunja nije othranio nijednog ptića, nedvojbeno je dokazano ponovno gniježđenje vrste nakon 50 godina izostanka. Tijekom zimovanja i gniježđenja u Hrvatskoj crvene lunje su koristile mozaična nizinska poljoprivredna područja s manjim njivama, livadama, drvoredima i šumarcima. Noviji podaci prikupljeni tijekom zimskog prebrojavanja ptica odnosno satelitskim praćenjem ptica iz sjevernijih populacija, pokazali su da je crvena lunja redovita preletnica u čitavoj Hrvatskoj te redovita zimovalica, prvenstveno u istočnoj Slavoniji i Baranji. Gnijezdeća populacija crvene lunje u srednjoj Europi pokazuje blago rastući trend te se u narednim godinama može očekivati eventualni pronalazak novih gnijezdećih parova i u Hrvatskoj. 